DOI: $10.1515 /$ hssr -2015-0003

\title{
Industries in Central and Eastern Europe. Enhancing Competitiveness by Integrating Services into Manufacturing
}

Sorin Burnete*

„Lucian Blaga” University of Sibiu

\begin{abstract}
During the last two decades, the intra-industry trade between western companies and former socialist enterprises in Central and Eastern Europe gradually shifted from the subcontracting of marginal operations such as final assembly to the outsourcing of products and intermediate inputs. To further enhance their competitiveness, firms in Central and Eastern Europe have yet to take one more step forward: integrate services with manufacturing. Developing such capabilities hinges, aside from intensive training and learning on the existence of functional interactive knowledgebased innovation systems. Whereas Central and East European economies exhibit conspicuous weaknesses in this last respect, they still possess a countervailing advantage that is apt to lure foreign investors into the region: lower wage rates relative to western countries across all industries and skill levels. Offshoring therefore seems to be the most appropriate means to reconcile the two sides of the coin.
\end{abstract}

Keywords

Offshoring, Servitization, Skill intensity, Supply chain JEL Codes: F16, F21, F29

\footnotetext{
* Department of Management, Marketing and Business Administration, 'Lucian Blaga” Uniersity, 17, Calea Dumbravii, Sibiu 550324; sorin.burnete@gmail.com
} 


\section{Competitiveness might wear thin if based solely on price}

The need to withstand stiff competition from both inside and outside the European continent is urging manufacturing firms in Central and Eastern Europe (hereinafter CEE firms) to enhance their competitiveness. Yet to accomplish this, what CEE firms need first and foremost is an outright change in their perception of the term, given that the bequest from the past from this point of view is rather misleading. Former communist regimes viewed competitiveness through the prism of a petty syllogism: productivity growth depresses production costs, thereby keeping prices low and boosting sales. In other words, the mere increase in productivity was deemed sufficient to make economies competitive. Yet reality has highlighted the fallacy of this notion: former COMECON countries generally scored significant growths in productivity, which nevertheless failed to translate into gains in competitiveness. Moreover, the mere confrontation with foreign competition in the early 1990s made the respective economies implode. Consequently, the following question is critical: what do CEE firms need to become competitive? UNIDO (1995) experts provided a clue: "while competitiveness in pricing is a necessary condition for export success, it is not sufficient. Exporters also need to be up to date about changes in customer preferences; to ensure the quality, timeliness and delivery of the goods produced; and to acquire the necessary marketing and distribution skills." In a nutshell, productivity growth is indeed an essential prerequisite for economic development; yet it is no guarantee for market success. Competitiveness actually hinges on a host of factors, most of them not price-related. As Ezeala-Harrison (1999) put it, "...a country would be losing international competitiveness if it suffers from such factors as: poor research and development (R\&D) record; a growing trade deficit in high-tech products; an ill-trained labor force, and declining productivity." $F$ rom among the non-price determinants of competitiveness, managerial factors have gotten particular importance because they strengthen firms' capacity to cope with environment changes. From this viewpoint, scholars emphasize two ways in which firms deal with environment changes, namely: "strategic agility", which refers to "firms' ability to benefit by such changes faster than their competitors" respectively "absorption", meaning firms' attempt to protect themselves from such changes by extending their scope or growing "too big to fail". ${ }^{2}$ 
CEE firms' competitiveness clearly hinges on their ability to respond to such imperatives as the ones emphasized earlier, more specifically, on the extent to which they will meet the " $3 p$ triad", that is propensity, preparedness and possibility of enhancing their market power in terms of both strategic agility and absorption capacity. Whereas strategic agility obviously depends on endogenous factors like quality of management, synergies etc., the absorption capacity compellingly implies an expansion in scope, whereby the firm is supposed either to embark on new types of activities or extend the existing ones in order to make their offerings more appealing to customers. I address this last issue in the remainder of the paper, which is organized as follows: the second chapter outlines Central and Eastern Europe's hallmarks as a potential target for the relocation of tasks by western firms. The third chapter includes a brief theory review of offshoring, with focus on chief motivations, scope and implications. In the fourth chapter, I try to assess CEE firms' preparedness for switching to servitization. I devoted the fifth chapter to some brief concluding remarks.

\section{Central and Eastern Europe's hallmarks as a potential target for the relocation of tasks by western firms}

There are plenty of ways by which a firm's absorption capacity might be increased. One strategic option, in line with a novel model in global business, involves combining manufacturing with services. Attaching a service component to the physical products delivered can free CEE firms from the straitjacket of purely cost-based competition, widening the range of their market opportunities and rendering them more customer-oriented. Yet CEE firms' possibility to infuse services into their total offerings is impaired by their scarce innovating capabilities. The economies in the region's lower innovative strength is, for historical reasons, rooted in their internal environments, which are poorly effective in stimulating the interaction of knowledge-based innovation systems.

CEE firms must therefore glean the required technical knowledge and skills from trade and investment relations with western partners insofar as the said relations allow for knowledge transmission. In other words, the region's industrial upgrading is contingent on offshoring. Danis and Parkhe (2002) identified three types of "international cooperative ventures" between western multinationals and CEE firms: shared equity 
HSS, vol. IV, no. 1 (2015): 30-42

joint ventures; acquisitions of eastern companies; contracted manufacturing arrangements. Such ventures, with or without FDI component, are supposedly conduits for transfers of technical and managerial knowledge. Asset ownership nevertheless makes a difference in that it allows for such transfers to occur all but automatically (Hardy, 2007), whereas knowledge transmission through arm's length trade is more problematic. Antràs et al. (2006) make a compelling argument as to why FDI-based arrangements are more efficacious vehicles: whereas western managers have strong incentives to form "cross-country teams" with workers from vertically integrated units, they would be reluctant to team up with workers from independent firms, most probably because of possible contractual frictions. All in all, in spite of local affiliates of western multinationals being better positioned to accomplish the target as long as they can take advantage from intra-firm transfers of technology and expertise, independent manufacturers do stand their chance in this drive in view of the fact that services inputs are less dependent on foreign investment but rather on self-induced technological and educational progress.

The targeting of Central and Eastern Europe for the offshoring of tasks by western firms is grounded on motivations that most certainly go beyond mere labor arbitrage. Contrary to the widespread belief that the sole reason why western firms are dealing with partners in the CEEs is to take advantage of lower wages, the latter can offer a wide range of business opportunities besides cheaper labor. For one thing, their workforce is sufficiently well trained to handle the special demands of knowledge and skilled labor intensive operations; for another, as Guzik and Micek (2008) noted, Central and Eastern Europe can offer nonnegligible market opportunities. In addition, Sass and Fifekova (2011) point to a number of country-specific features e.g. quality of infrastructure, political and business environment, cultural affinity, government incentives etc. that can help lure foreign businesses into the region. Last but not least, CEE firms' technological upgrading is going on apace, as a number of recent surveys on European manufacturing industry have emphasized. ${ }^{3}$ 
HSS, vol. IV, no. 1 (2015): 30-42

\section{Offshoring: motivations, implications and scope. \\ Brief theory review}

Recent literature has dealt extensively with firms' motivations to shift activities offshore, whether through capital investment or arm's length trade, as well as with implications of this kind of trade. Motivations can be expressed generically by the "make-or-buy" dichotomy that is the firm's discretion to opt between two alternatives concerning the procurement of intermediate inputs and services: to produce them internally or contract them out to independent suppliers. Thus, in a broader approach, firms' decision to relocate activities outside their boundaries is basically a problem of corporate organization efficiency. As Grossman and Helpman (2002) put it, there is a "trade-off between the costs of running a large and less specialized organization and costs that arise from search frictions and imperfect contracting". On the other hand, offshoring allows firms to cut back on labor costs by employing lower wage workers. Moreover, when firms are in dire straits, the decision to shift activities offshore becomes a key strategy for higher profitability and sometimes even corporate survival. (Kohler, 2004) Eventually, even those tasks that use knowledge and high skilled labor intensively will be relocated or contracted out to firms in lower wage countries in order for contracting firms to capitalize on labor costs.

Offshoring has been constantly growing in scope. According to Antràs (2005), international trade in tasks - whether physical inputs or intangibles - is duly compatible with Vernon (1966)'s product cycle hypothesis: as production becomes standardized, firms tend to transfer it, partly or entirely, offshore, while keeping in-home mostly non-routine tasks, which use knowledge and high skills intensively. Yet trade in this kind of services has also been booming lately. Since services vary in knowledge and skill intensity (Kucza and Gebauer, 2011), they are, the same as physical products, subject to standardization criteria. This particular trait makes product-related services - "from basic research to product design, from preparation and installation of machinery and the production of components, to assembly, packing, marketing, and shipping" (Grossman and Helpman, 2002) - apt to be relocated offshore. As Guzik and Micek (2008) point out, it is not just routine services that make up the object of offshoring but also those that 
engender high skills and knowledge. Briefly, the scope of offshoring is expanding, with or without capital investment. However, international trade in intangibles is more risky and complex as compared to the one in goods due to "the inherent characteristics of services", which imply "local presence and customer-supplier interactions". However, as scholars (e.g. Kowalkowski et al., 2011) suggest, despite such inconveniences, trade in all categories of business services including the ones that are intended to support product offerings will explode in the future.

Whereas motivations are most often related to microeconomic strategies, implications are preponderently macroeconomic. Offshoring as measured by international trade in intermediate inputs within industries is widely considered responsible for low skilled workers' declining relative wages and loss of jobs in developed countries during the last decades. Up to a point, the presumed causal link between offshoring and the upward trend of skilled workers' relative wages in developed countries is in concordance with standard theory predictions: first, the transfer of low-tech activities to low-wage countries fits the ricardian-type specialization pattern (the latter have comparative advantage in low-tech activities due to their relatively lower average productivity). Second, the process is consistent with Heckscher-Ohlin's factor proportion theorem (low skilled labor-abundant countries tend to specialize in low-tech activities, which use low skilled labor intensively). Third, the decline in low skilled workers' wages is due to the StolperSamuelson effect: international trade in labor intensive goods lowers the price of such goods in developed countries and as a consequence, the price of low skilled labor decreases in both relative and absolute terms. Reality nevertheless has confirmed these predictions only in part: unexpectedly, unskilled workers wages fell in both home and host countries. Feenstra and Hanson (1996) and Feenstra (1998) indicated outsourcing as the chief source of distortion: since outsourced activities are more skilled labor intensive than those initially performed by the host country but less skilled labor intensive than the ones the home country continues to keep inside its boundaries, a skill bias will ensue in the demand for labor in both countries concomitantly. Hsieh and Woo (2005) found evidence of "strong and persistent relative demand shifts 
favouring skilled workers in Hong Kong since the early 1980s, which is when outsourcing to China started to take off'. As for the unskilled in either home and host countries, it is less clear whether international outsourcing has made them worse off in real terms or they only suffered a relative loss. Feenstra and Hanson (1996), using aggregate industrylevel data suggest the increasing wage gap between skilled and unskilled workers has not necessarily translated into a loss in real terms for either category, whereas Geishecker and Görg (2008), using individual-level data, found that international outsourcing had reduced the real wage for workers in the lowest skill categories.

\section{How well-prepared are CEE firms to embrace servitization?}

Integration of manufacturing and services aka servitization (Vandermerwe and Rada, 1988) will most likely be a trial of strength for all CEE firms. This should not be surprising in view of the fact that more experienced western firms are themselves encountering difficulties in this process. Qualities reflecting organizational change flexibility e.g. casualization of labor, delayering of production or non-linear sequencing of priorities (Sennett, 2004) will probably make a great deal of difference as regards the speed at which various individual firms will succeed in attaining the target. From a broader perspective, Lay et al. (2010) point to three attributes that reflect firms' capacity to integrate services into their product offerings, namely: level of strategic service orientation; type of products offered; position in the supply chain. The state of CEE firms in these respects is discussed below.

Strategic orientation: according to empirical evidence there has been an upturn in the service content of manufacturing industries in a number of CEEs since the mid 1990smid-1990s although the share of services in total output in the region at large is still low as compared to the west. ${ }^{4}$ While this development can surely be a signal that CEE firms are attaching growing importance to the service business, it is not telling enough as to the latter's strategic commitment thereto if any. Information sparseness and the actual low degree of services content should induce one to reasonably infer that CEE firms' level of strategic service orientation is wanting. Yet this fact is understandable given the insufficiency of knowledge and scarcity of practical experience in the 
field. According to Gebauer (2010), most economic and strategic arguments underlying firms' service orientation i.e. higher profitability, less volatility of revenues, greater potential to create competitive advantages etc. relative to manufacturing, are disputable. Since such micromanagement issues fall outside the scope of this paper, I will not expand on them.

Type of product: the type of product offered fosters the service business development to a degree that depends on industrial sectors' innovation intensity. ${ }^{5}$ Recent research has shed more light upon the hypothesized correlation between innovation intensity at sector level and the supply of product-related services: highly innovative manufacturing sectors not only have a higher share of services in total output but basically, they provide knowledge-intensive business services (KIBS). ${ }^{6}$ From this point of view, the difference between western countries and the CEEs is glaring: the former have a much greater share of KIBS in total service output relative to the latter. However, the KIBS intensity of CEEs' exports has risen substantially lately, despite their relatively weak position on the market of technology intensive goods. ${ }^{7}$ The main drivers have been western firms, especially from countries situated at CEEs' doorstep, which are increasingly capitalizing on the latter's reportedly well-trained but cheaper workforce.

Position in the supply chain: the relevance of the third attribute may not be strikingly evident at first glance. Yet it becomes clearer if service business is looked upon as an "application of competences (knowledge and skills) by one entity for the benefit of another". (Vargo et al., 2008) From this perspective, value is co-created through the action of knowledge and skills of participants placed at all levels of the supply chain. It follows that service opportunities are equally available to companies placed downstream and upstream in the supply chain. (Lay et al., 2010) In either case, firms' shift to service provision entails undergoing particular organizational, financial and behavioral changes, depending on the type of product supplied. In innovation intensive limited-run manufacturing industries, monitoring the way products meet customers' expectations is a key-element of firms' strategies. Consequently, activities positioned more upstream in the supply chain, related to product design and performance enhancement usually yield 
higher value added than the ones located more downstream, related to sales and maintenance. An illustrative example is offered by the European industry of computer services and software, as described by Guzik and Micek (2008): the low value added segments of the value chain are sales and basic software maintenance and this is where most of CEE software companies operate, whereas high value added segments like product development and systems design are less subject to outsourcing. Yet after a while, the above cited authors underscore, a large number of high-skilled operations will also be moved eastward.

By comparison, CEE firms operating in low and medium innovation intensive industries have long been engaged in contracted manufacturing arrangements whereby they were assigned low skill intensive tasks like assembly of imported inputs, a formula that has come to be the epitome of exports of cheap labor. Under such conditions, upgrading entails going downstream that is attempting to penetrate distribution channels in order to get nearer to final consumers. Scholars (e.g. Gereffi, 1999) suggest that, to accomplish this firms must shift to more complex forms of exporting like full-package supply, aka original equipment manufacturing (OEM), involving aside from assembly, the provision of a set of supporting services: design, product development, production and inventory management, procurement of inputs, quality supervision, financing, accounting, advertising, delivery scheduling etc. Aside from that, at this level production and sales usually occur within networks. Research of supply relationships and value chain dynamics (Sturgeon and Lee, 2001; Gereffi et al., 2005) has provided an insight as to how firms accede to superior forms of value chain governance, which facilitate organizational learning, knowledge exchange and in general, more efficient coordination of production and appropriation and distribution of value. (Smith, 2003)

\section{Concluding remarks}

Services related to manufacturing, which firms tend to sell alongside the main product with the aim of raising the overall value of their offerings, account for an ever growing share of global trade. The increasing importance of this type of trade is not fortuitous: it is due to servitization being considered as a trademark of success in today's global 
business. In this context, CEE firms though lagging behind in terms of technological upgrading have no other option but struggle to jump in the bandwagon. Yet because of their relatively low innovating capability, succeeding in this undertaking is, at least for the time being, contingent on western firms' will to shift skill and knowledge intensive tasks eastward. All in all, offshoring remains the paramount vehicle for information spillover and technology transmission toward the region.

\section{References}

Antràs, P. "Incomplete Contracts and the Product Cycle". The American Economic Review. 95/4 (2005): 1054-73.

Antràs, P., L. Garicano, E. Rossi-Hansberg. "Offshoring in a Knowledge Economy". The Quarterly Journal of Economics 121/1 (2006): 31-77.

Danis, W.M., A. Parkhe. "Hungarian-Western Partnerships: A Grounded Theoretical Model of Integration". Journal of International Business Studies 33/3. (2002): 423-455.

European Commission. European Competitiveness Report 2011 (2011): 79-80 (available at http://ec.europa.eu/enterprise/newsroom/cf/_getdocument. cfm?doc_id=7002).

Ezeala-Harrison F. (1999) Theory and Policy of International Competitiveness, Praeger, London, 1999. 3-78.

Feenstra, R.C., G. Hanson. "Foreign Investment, Outsourcing and Relative Wages". The Political Economy of Trade Policy: Papers in Honor of Jagdish Bhagwati, Feenstra, C; Grossman, G.; Douglas, A. eds., MIT Press: Cambridge, MA, 1996. 89-127.

Gebauer, H. "Service Business in Manufacturing Companies: Identifying Misconceptions and Directing Further Research". Journal of Applied Management and Entrepreneurship (2010): 15/3.

Geishecker, I., H. Görg. "Winners and Losers: A Micro-Level Analysis of International Outsourcing and Wages". The Canadian Journal of Economics / Revue canadienne d'Economique 41.1 (2008): 243-270.

Gereffi, G. "International Trade and Industrial Upgrading in the Apparel Commodity Chain". Journal of International Economics 48/1 (1999): 37-70.

Gereffi, G., J. Humphrey, T. Sturgeon. "The governance of global value chains". Review of International Political Economy 12 (2005): 78-104.

Grossman, G.M., E. Helpman, E. "Integration versus Outsourcing in Industry Equilibrium". The Quarterly Journal of Economics 117/1 (2002): 85-120. 
Guzik, R., G. Micek. "Impact of Delocalization on the European Software Industry". L. Labrianidis (red.), The Moving Frontier: The Changing Geography of Production in Labour Intensive Industries, Ashgate, 2008. 229-254 (available at http://www.geo.uj.edu.pl/zaklady/zrr/publikacje/pdf/software\%20industr yGuzik\%20Micek.pdf)

Hardy, J. 2007. The New Competition and the New Economy: Poland in the International Division of Labour. Europe-Asia Studies 59/5 (2007): 761-77.

Hsieh, C-T, K.T. Woo. 2005. The Impact of Outsourcing to China on Hong Kong's Labor Market. The American Economic Review 95, no. 5: 1673-1687

Kohler, W., "International Outsourcing and Factor Prices with Multistage Production." The Economic Journal. 114/494 (2004): C166-C185

Kravis B., R. Lipsey. Price Competitiveness in World Trade, NBER, 1971.

Kowalkowski C., Kinström D., Brehmer P-O. "Managing industrial service offerings in global business markets". Journal of Business \& Industrial Marketing, vol. 26/3 (2011): 181-192.

Kucza, G., H. Gebauer. "Global approaches to the service business in manufacturing companies". Journal of Business \& Industrial Marketing 26/7 (2011): 472-83.

Lay, G., G. Copani, A. Jäger, S. Biege. "The relevance of service in European manufacturing industries". Journal of Service Management 21/5 (2010): 715-26 (available at http://www.emeraldinsight.com/journals.htm?issn=17575818).

Peneder, M. "Technological regimes and the variety of innovation behaviour: creating integrated taxonomies of firms and sectors". Research Policy 39/3 (2010): 323-334.

Sass, M., M. Fifekova. "Offshoring and Outsourcing Business Services to Central and Eastern Europe: some Empirical and Conceptual Considerations". European Planning Studies 19/9 (2011): 1593-1609.

Sennett, R. The Culture of the New Capitalism. Yale University Press, 2006.

Smith, A. "Power Relations, Industrial Clusters, and Regional Transformations: Pan-European Integration and Outward Processing in the Slovak Clothing Industry". Economic Geography 79/1 (2003): 17-40.

Sturgeon, T., J-R Lee. "Industry Co-Evolution and the Rise of a Shared Supply-Base for Electronics Manufacturing". Paper Presented at Nelson and Winter Conference, Aalborg, Denmark, 2001. Draft May 21 (available at http://www.inti.gov.ar/cadenasdevalor/documentacion/sturgeon_Lee. pdf). $\backslash$

UNIDO. "Industrial Development, New concept of industrial competitiveness". Global Report. (1995) : 23-29. 
HSS, vol. IV, no. 1 (2015): 30-42

Vandermerwe, S., J. Rada. "Servitization of business: adding value by adding services". European Management Journal 6/4 (1988): 314-324.

Vernon, R. "International Investment and International Trade in the Product Cycle". The Quarterly Journal of Economics 80/2 (1966): 190-207.

Vargo, S.L., P.P. Maglio, M.A. Akaka. "On value and value co-creation: A service systems and service logic perspective". European Management Journal 26/3 (2008): 145-52.

${ }^{1}$ In fact, the growing importance of non-price factors in competitiveness determination has been emphasized by scholars ever since the 1960s. A survey cited by Kravis \& Lipsey (1971), undertaken in 1964 by a group of researchers from the National Association of Business Economists on 100 US-based exporting firms concluded that the interviewed firms had devoted to price no more than 28 percent of the efforts within the international competitiveness strategy. The remainder was held by other factors like: trade mark, promptness in delivery, quality of post-sale services etc.

2 Don Sull, from London Business School, quoted by The Economist ("European companies face competition from new directions" - The Economist, Feb. $8^{\text {th }}, 2007$ )

3 The last survey was performed in 2009 by the Austrian Institute of Technology and the Fraunhofer ISI on 21 European countries and the US. ("The servitization of European manufacturing industries", MPRA paper nr. 38873/2012) A similar survey had been performed in 2004 (European Manufacturing Survey, Bulletin nr.1, Dec. 2005, http://ref.sabanciuniv. edu/sites/ref.sabanciuniv.edu/files/emis_bulletin_1.pdf)

${ }^{4}$ The share is around 2 percent in the CEEs whereas in the West the average share is 4 percent, reaching $8-9$ percent in countries like Finland and the Netherlands. (MPRA paper nr. 38995/2012)

${ }^{5}$ A comprehensive industrial taxonomy according to innovation intensity can be found in Peneder (2010).

${ }^{6}$ A KIBS taxonomy is available in Eurostat: NACE Rev.2, Statistical classification of economic activities in the European Union, 2008.

${ }_{7}^{7}$ For a comparative analysis of the dispersion of production and trade in KIBS across the European Union, see European Commission, European Competitiveness Report 2011. 


\section{Biographical note}

Sorin Burnete, Ph.D., is professor of at the Lucian Blaga University of Sibiu. His academic background was completed by one year training at the University of Missouri. He was, for six years consecutively, visiting professor at J.W. University of Frankfurt/Main. He authored a number of books, monographs, textbooks dealing with many a topic in such fields as international trade, economic policy, international business, economic history, central banking. $\mathrm{He}$ also published several articles in international journals such as: "Romania's Economic Policy - the Rulers' Wisdom Will Lead Us" (Journal of Organizational Change Management); "New EU Member Countries are Phasing Out Labor-Intensive Activities: An Econometric Approach" (Studies in Business and Economics) etc. 